\title{
ANALISIS FAKTOR-FAKTOR YANG MEMPENGARUHI FINANCIAL LITERACY DI KALANGAN MAHASISWA UNIVERSITAS MUHAMMADIYAH RIAU (UMRI) PEKANBARU
}

\author{
ANALYSIS OF FACTORS AFFECTING FINANCIAL LITERACY AMONG \\ UNIVERSITY STUDENTS MUHAMMADIYAH RIAU (UMRI) PEKANBARU
}

\author{
Mimelientesa Irman \\ Sekolah Tinggi Ilmu Ekonomi Pelita Indonesia \\ Teshairman@ymail.com
}

\begin{abstract}
Financial literacy is a basic need for everyone to avoid financial problems. This study aims to find out how the level of financial literacy students of Muhammadiyah University of Riau Pekanbaru. This research concerned were knowledge of personal finance, savings and loans, insurance and investment. Respondents in this study were 91 active students at Muhammadiyah University of Riau. The method used in this research is descriptive method and binary logistic test. The results showed that the students' financial literacy influenced by GPA of students, while gender and work experience have no significant influence on student's financial literacy.
\end{abstract}

Keywords: Financial Literacy, Gender, GPA, Work Experience

\begin{abstract}
ABSTRAK
Financial literacy merupakan kebutuhan dasar bagi setiap orang agar terhindar dari masalah keuangan. Penelitian ini bertujuan untuk mengetahui bagaimana tingkat literasi keuangan mahasiswa Universitas Muhammadiyah Riau Pekanbaru. Aspek yang diteliti adalah pengetahuan tentang keuangan pribadi, simpan pinjam, asuransi dan investasi. Responden pada penelitian ini sebanyak 91 orang mahasiswa aktif di Universitas Muhammadiyah Riau. Metode yang digunakan dalam penelitian ini adalah metode deskriptif dan uji logistik biner. Hasil penelitian menunjukkan bahwa literasi keuangan mahasiswa dipengaruhi faktor berupa IPK, sedangkan faktor jenis kelamin dan pengalaman kerja tidak memberikan pengaruh signifikan terhadap literasi keuangan mahasiswa.
\end{abstract}

Kata Kunci : Literasi Keuangan, Jenis Kelamin, IPK, Pengalaman Kerja

\section{PENDAHULUAN}

Salah satu kecerdasan yang harus dimiliki oleh manusia modern adalah kecerdasan finansial, yaitu kecerdasan dalam mengelola aset keuangan pribadi. Memiliki pengetahuan dan melakukan perencanaan keuangan merupakan proses mencapai tujuan hidup yakni masa depan yang sejahtera dan bahagia lewat penataan keuangan. Tanpa adanya perencanaan keuangan maka hidup yang bagi sebagian besar anggota masyarakat sudah sulit akan menjadi sangat sulit. Dan dengan menerapkan cara pengelolaan keuangan yang benar, maka individu diharapkan bisa mendapatkan manfaat yang maksimal dari uang yang dimilikinya. Oleh karena itu, individu harus memiliki suatu pengetahuan dan keterampilan untuk mengelola sumber keuangan pribadinya secara efektif demi kesejahteraannya.

Financial Literacy atau literasi keuangan lebih dikenal dengan pengetahuan dalam pengaturan keuangan adalah salah satu perilaku ekonomi yang berkembang di masyarakat dengan sadar ataupun tidak sadar telah dijalani selama bertahun-tahun. Financial literacy merupakan kebutuhan dasar bagi setiap orang agar terhindar dari masalah keuangan. 
Financial literacy dapat diartikan sebagai pengetahuan keuangan dengan tujuan mencapai kesejahteraan (Lusardi \& Mitchell 2007). Orton (2007) memperjelas dengan menyatakan bahwa literasi keuangan menjadi hal yang tidak terpisahkan dalam kehidupan seseorang karena literasi keuangan merupakan alat yang berguna untuk membuat keputusan keuangan yang terinformasi, namun dari pengalaman-pengalaman di berbagai negara masih menunjukkan relatif kurang tinggi.

Indonesia adalah negara berkembang yang terkena dampak dari krisis global. Selain karena sistem keuangan yang masih kurang baik, tingkat literasi keuangan yang rendah dari masyarakat Indonesia juga turut mempengaruhi perekonomian Indonesia. Otoritas Jasa Keuangan juga melakukan survei untuk mengetahui tingkat literasi keuangan pada masyarakat Indonesia pada tahun 2013. Survei dialkukan di 20 provinsi dengan jumlah responden 8.000 penduduk (Otoritas Jasa Keuangan, 2014). Hasil survei tersebut ditunjukkan pada tabel berikut ini

Tabel 1. Indeks Literasi dan Indeks Utilitas Sektor Keuangan (\%_)

\begin{tabular}{lcccccc}
\hline & Bank & Asuransi & $\begin{array}{c}\text { Perusahaan } \\
\text { Pembiayaan }\end{array}$ & $\begin{array}{c}\text { Dana } \\
\text { Pensiun }\end{array}$ & $\begin{array}{c}\text { Pasar } \\
\text { Modal }\end{array}$ & Pegadaian \\
\hline $\begin{array}{l}\text { Well } \\
\text { Literate }\end{array}$ & 21,80 & 17,84 & 9,80 & 7,13 & 3,79 & 15,85 \\
\hline $\begin{array}{l}\text { Sufficient } \\
\text { Literate }\end{array}$ & 75,44 & 41,69 & 17,89 & 11,74 & 2,40 & 38,89 \\
\hline $\begin{array}{l}\text { Less } \\
\text { Literate }\end{array}$ & 2,04 & 0,68 & 0,21 & 0,11 & 0,03 & 0,83 \\
\hline $\begin{array}{l}\text { Not } \\
\text { Literate }\end{array}$ & 0,73 & 39,80 & 72,10 & 81,03 & 93,79 & 45,44 \\
\hline & & & & & & \\
\hline Utility & 57,28 & 11,81 & 6,33 & 1,53 & 0,11 & 5,04 \\
\hline
\end{tabular}

Sumber:OJK, 2014.

Tabel diatas menyatakan bahwa masyarakat yang memiliki literasi keuangan yang baik hanya sebesar $21,80 \%$ untuk perbankan, $17,84 \%$ untuk asuransi, 9,80\% untuk perusahaan pembiayaan, $7,13 \%$ untuk dana pensiun, 3,79\% untuk pasar modal dan $15,85 \%$ untuk pegadaian. Jumlah indeks masyarakat Indonesia yang well literate jauh lebih kecil dibandingkan dengan masyarakat Indonesia yang sufficient literate. Ini menunjukkan indeks utilitas sektor keuangan yang mencerminkan pemanfaatan produkproduk keuangan juga terbilang masih rendah (Kardinal, 2015). Dan pada tahun 2017, Direktur Permata Bank Bianto Surodjo menjelaskan saat ini sebagian besar masyarakat di Indonesia belum terlalu sadar akan pentingnya kegiatan finansial. Berdasarkan hasil riset hampir 80\% masyarakat di Indonesia belum sadar pentingnya kegiatan finansial. Menurut Direktur Literasi dan Edukasi Keuangan Otoritas Jasa Keuangan (OJK) Horas Tarihoran berpendapat tingkat literasi masyarakat terhadap kegiatan finansial hanya sekitar 29,6\% saja. Ini termasuk kedalam kondisi yang tidak normal karena literasi yang rendah tapi pengguna keuangan justru tinggi (Kumparan, 02 Agustus 2017).

Perekonomian nasional tidak akan mudah tergoyahkan atau terimbas oleh berbagai krisis keuangan dunia jika masyarakat memahami sistem keuangan (Kompas, 21 Oktober 2008). Hal ini menjadi pemicu agar individu mengetahui financial literacy yaitu kemampuan untuk memproses informasi-informasi keuangan untuk menetapkan keputusan dalam pengetahuan keuangan pribadi. Bagaimana meningkatkan aset, merencanakan pensiun, meminjam dengan bijaksana, meningkatkan tabungan dari kesadaran dan rencana individu.

Baik orang kaya atau miskin, pandai atau bodoh, tua atau muda, semua memiliki persamaan kalau sudah sampai pada urusan uang. Kita semua menggunakan uang. Jumlah uang yang dimiliki dan bagaimana cara kita menggunakan uang berbeda satu sama lain. Namun, yang pasti di dunia ini kita semua memerlukan uang. Kegiatan mengelola keuangan untuk pemenuhan kebutuhan konsumsi sehari-hari sehingga hingga proses persiapan jangka panjang dalam bentuk tabungan juga merupakan bagian dari financial literacy.

Literasi keuangan dipengaruhi oleh beberapa faktor antara lain jenis kelamin, 
indeks prestasi kumulatif dan pengalaman kerja. Berbagai penelitian terdahulu menjelaskan bahwa jenis kelamin mempengaruhi literasi keuangan karena terdapat perbedaan pandangan antara mahasiswa laki-laki dan mahasiswa perempuan dalam mengelola keuangan. Indeks prestasi kumulatif menunjukkan bahwa semakin tinggi IPK, maka mahasiswa semakin baik dalam mengelola keuangan pribadinya. Pengalaman kerja juga berpengaruh positif terhadap literasi keuangan. Ada perbedaan pendapat menurut Rita dan Pusedo (2014) menyatakan bahwa jenis kelamin dan indeks prestasi kumulatif tidak berpengaruh terhadap literasi keuangan. Sedangkan Ariani dan Susanti (2015) menyatakan bahwa jenis kelamin dan pengalaman bekerja tidak berpengaruh terhadap literasi keuangan mahasiswa.

Mahasiswa merupakan salah satu komponen masyarakat dengan jumlah yang cukup besar dalam memberikan sumbangsih terhadap perekonomian (Nababan \& Sadalian, 2012). Mahasiswa juga salah satu komponen masyarakat yang tergolong berpendidikan tinggi, maka sudah seharusnya mahasiswa memiliki tingkat literasi yang baik. Namun fenomena yang ada sekarang di kalangan mahasiswa, terutama mahasiswa yang mengatur kebutuhan konsumsinya secara mandiri, dari hasil pendapatan orang tua maupun mandiri, mereka menjalani berbagai kegiatan ekonomi yang tidak proporsional.

Kecendrungan ini terlihat dari tidak adanya pembentukan skala prioritas atas kegiatan ekonominya, seperti pola konsumsinya yang kurang terprogram dan tidak ada pertimbangan konsumsi, dan pertimbangan akan kebutuhan lainlainnya. Terkadang pula, dalam pemenuhan hasratnya akan suatu barang, mereka cenderung untuk mengurangi alokasi atas kebutuhan pokok mereka. Selain itu, keadaan lingkungan pertemanan didukung dengan banyaknya fasilitasfasilitas hiburan dan wisata kuliner yang menggiurkan sedikit banyak memberi dampak terhadap pengaturan keuangan dan pola konsumsi mahasiswa pada umumnya.

Rasa sungkan, dan persaingan dalam pertemanan terkadang juga membuat pola konsumsi yang tidak rasional dan diakhirnya akan mempengaruhi keadaan finansial sendiri. Pertanggung jawaban finansial kepada orang tua yang tidak terpenuhi, disinyalir pula dapat menyebabkan keterlambatan anak dalam memahami apa pentingnya pengaturan keuangan sendiri.

Fakultas ekonomi adalah salah satu fakultas yang memiliki jumlah mahasiswa yang cukup besar diantara fakultas lain yang ada di Universitas Muhammadiyah Riau Pekanbaru. Dalam masa perkuliahannya mahasiswa fakultas ekonomi dibekali dengan materi-materi mengenai manajemen keuangan, pengendalian manajemen dan lainnya guna memperkaya wawasan tentang keuangan maupun ekonomi yang akhirnya menambah pengetahuan keuangan atau literasi keuangan sebagai bekal dalam mengelola dan mengambil keputusan keuangan yang akan mempengaruhi kesejahteraan dan keberhasilannya di masa depan. Namun, belum seluruh mahasiswa mampu mengelola keuangannya dengan baik karena dalam masa kuliah menjadi saat pertama bagi mahasiswa mengelola keuangan sendiri tanpa diawasi oleh orang tua.

Mengingat pentingnya financial literacy maka BEI Perwakilan Riau melakukan edukasi financial dengan melakukan kerja sama di beberapa perguruan tinggi di kota Pekanbaru dalam upaya meningkatkan pengetahuan mahasiswa akan produk-produk investasi dan manajemen keuangan pribadinya.Edukasis dilakukan pada dua universitas negeri yaitu Universitas Riau dan UIN Sultan Syarif Kasim, dan empat Universitas swasta yaitu Universitas Politerknik Caltex, Universitas Muhammadiyah Riau, Universitas 
Lancang Kuning dan STIE Pelita Indonesia (Market, 2016).

Hasil survei yang dilakukan terhadap

20 Mahasiswa Akuntansi Universitas Muhammadiyah Riau Pekanbaru mengindikasikan bahwa rata-rata $60 \%$ mahasiswa telah memiliki kemampuan mengelola keuangan dengan baik. Hasil survei menunjukkan bahwa tidak semua mahasiswa mengalokasikan uangnya untuk keperluan makan, perlengkapan kuliah, transportasi dan ke tempat-tempat hiburan. Mahasiswa secara rutin melakukan pembayaran tagihan tepat waktu seperti biaya semester kuliah, listrik dan lainnya.Mahasiswa juga melakukan perbandingan harga antar toko atau swalayan atau supermarket sebelum melakukan keputusan pembelian untuk menghemat biaya pengeluaran.

Hasil survei menunjukkan bahwa sebesar $60 \%$ mahasiswa mempunyai alokasi dana untuk ditabung, terutama mahasiswa semester 5 dan semester 7 . Dengan alasan pendapatan dimasa depan yang tidak tentu dan perencanaan tabungan masa depan jika sewaktu-waktu membutuhkan uang atau pengeluaran tidak terduga. Survei untuk asuransi menunjukkan bahwa tidak terdapat mahasiswa yang membayar asuransi diri sendiri karena kurang pentingnya asuransi bagi mereka dan kurangnya informasi mengenai produk asuransi.

Survei investasi sebesar $30 \%$ dari keseluruhan mahasiswa dengan bentuk investasi barang seperti emas yang dilakukan oleh mahasiswa semester 3, semester 5 dan semester 7.Sedangkan mahasiswa semester 1 belum melakukan investasi.

Tujuan penelitian ini adalah untuk menganalisis pengaruh jenis kelamin, indeks prestasi kumulatif (IPK) dan pengalaman kerja terhadap tingkat financial literacy padaMahasiswa Jurusan Akuntansi S1 Universitas Muhammadiyah Riau (UMRI) Pekanbaru.
Menurut Manurung (2009) literasi keuangan adalah seperangkat keterampilan dan pengetahuan yang memungkinkan seorang individu untuk membuat keputusan yang efektif dengan semua sumber daya keuangan mereka. Sedangkan menurut Lusardi dan Mitchell tahun 2007 (dalam Rasyid, 2012) literasi keuangan dapat diartikan sebagai pengetahuan keuangan dengan tujuan mencapai kesejahteraan. Hal ini dapat dimaknai bahwa persiapan perlu dilakukan untuk menyongsong globalisasi, lebih spesifiknya globalisasi dalam keuangan tentang bagaimana mengelola keuangan serta bagaimana teknik berinvestasi yang nantinya bisa jadi hal yang tidak dapat diabaikan seperti waktu-waktu seperti sebelum-sebelumnya.

Menurut Bhushan and Medury (2013) menjelaskan literasi keuangan sangat penting karena beberapa alasan "Pertama konsumen yang memiliki literasi keuangan bisa melalui masa-masa keuangan yang sulit karena faktanya bahwa mereka mungkin memiliki akumulasi tabungan, membeli asuransi dan diverifikasi investasi mereka. Kedua, literasi keuangan juga secara langsung berkolerasi dengan perilaku keuangan yang positif seperti pembayaran tagihan tepat waktu, angsuran pinjaman, tabungan sebelum habis dan menggunakan kartu kredit secara bijaksana.

Arif (2015) literasi keuangan didefinisikan sebagai pengetahuan dan pemahaman konsep keuangan, kemampuan, motivasi dan kepercayaan dalam mengaplikasikan beberapa pengetahuan dan pemahaman yang tertata dalam membuat keputusan efektif pada lingkup konteks keuangan untuk memperbaiki kesejahteraan keuangan masyarakat dan individu serta memungkinkan untuk ikut serta dalam kehidupan ekonomi.

Menurut Huston (2010), literasi keuangan adalah sebuah bagian dari modal manusia yang dapat digunakan dalam kegiatan keuangan untuk meningkatkan 
manfaat seumur hidup yang diharapkan dari konsumsi. Kharchenko (2011)menyatakan bahwa literasi keuangan adalah sebuah keterampilan numerik yang diperlukan dan pemahaman terhadap konsep dasar ekonomi yang dibutuhkan untuk mendidik dalam keputusan menyimpan dan meminjam. Mendari dan kewal (2014) literasi keuangan merupakan dasar bagi setiap orang agar terhindar dari masalah keuangan.

Menurut Otoritas Jasa Keuangan, literasi keuangan didefinisikan sebagai rangkaian proses atau aktivitas untuk meningkatkan pengetahuan (knowledge), keyakinan (competence), keterampilan (skill) konsumen dan masyarakat luas sehingga mereka mampu mengelola keuangan dengan lebih baik (Otoritas Jasa Keuangan, 2014). Simpulan atas pendapat diatas yaitu literasi keuangan merupakan pengetahuan yang dapat membantu dalam memberikan pemahaman kepada individu tentang mengelola keuangan untuk mencapai kehidupan yang lebih sejahtera dimasa yang akan datang.

Remund (2010) menyatakan empat hal yang paling umum dalam financial literacy adalah penganggaran, tabungan, pinjaman dan investasi. Seorang entrepreneur perlu memiliki kemampuan untuk mengelola sumber daya, baik dari dalam dirinya sendiri maupun dari luar dirinya agar dapat memaksimalkan potensi dalam mengelola kekayaannya. Dalam hal ini ada 4 (empat) aspek yang perlu diketahui mengenai financial literacy yaitu : Yang Pertama yaitu aspek bagaimana mendapatkan uang, melalui aspek ini kita dibimbing untuk menekuni bakat atau potensi yang dimiliki menjadi profesi yang menghasilkan uang baik melalui jalur formal maupun informal. Dari aspek ini kita akan mendapatkan pendapatan dari profesi yang dijalani. Misalnya akuntan, auditor, dosen, dokter, pengacara pilot, militer, seniman, pengusaha dan profesi lainnya. Yang kedua yaitu aspek bagaimana mengelola uang, melalui aspek ini kita diajari bahwa berapapun gaji atau pendapatan besar yang kita dapatkan, perlu menyisihkan sebagian dari pendapatan kita untuk investasi yang berpotensi memberikan pendapatan selain pendapatan yang telah kita jalani. Bukan hanya sekedar menyisihkan sebagian untuk tabungan hari tua kita. Oleh karena itu, pendapatan bisa dibagi atas 4 macam pengeluaran yaitu consumption, social, saving and investation. Misalnya sebagai perbanding secara berturut-turut adalah 70 : 10 : 10 : 10. Apabil pendapatan kita sebesar Rp. 1.000.000 maka dapat dibagi menjadi Rp. 700.000 untuk konsumsi, Rp. 100.000 untuk social(termasuk sumbangan gereja atau zakat), Rp. 100.000 untuk tabungan dan Rp. 100.000 untuk investasi. Semakin besar pendapatan maka porsi konsumsi semakin kecil sehingga porsi yang lain lebih besar. Namun bagi sebagian individu pada saat tingkat pendapatan meningkat, itu juga diikuti oleh tingkat pengeluaran. Aspek ini merupakan aspek yang cukup berat bagi seseorang karena menuntut kecerdasan emosi yaitu mampu menunda kesenangan sehingga pendapatan mereka tidak habis pada porsi konsumsi. Yang ketiga yaitu aspek bagaimana menyimpan uang/harta kekayaan, aspek ini merupakan upaya melindungi harta kekayaan agar tidak terkikis nilainya oleh laju inflasi. Bahkan, tidak sekedar melindungi nilai tetapi berpotensi melipatkan pendapatan dan kekayaan apabila bisa menyimpannya dengan tepat. Yang keempat yaitu aspek bagaimana menggunakan uang/kekayaan, aspek ini merupakan hal vital untuk mendapatkan kehidupan yang sejahtera dan berkualitas. Dalam hal ini kita harus menjadi konsumen yang cerdas. Kita perlu membuat skala prioritas dengan mempertimbangkan kebutuhan terlebih dahulu daripada keinginan. Terkdang dalam pemenuhan keinginan akan suatu barang, kita cenderung untuk mengurangi alokasi atas kebutuhan pokok kita

Widayati (2012) mengembankan 15 (lima belas) indikator literasi keuangan 
yang telah disesuaikan dengan kondisi di Indonesia yaitu : (1) Mencari pilihanpilihan dalam berkarier. (2) Memahami faktor-faktor yang mempengaruhi gaji bersih. (3) Mengenal sumber-sumber pendapatan. (4) Menjelaskan bagaimana mencapai kesejahteraan dan memenuhi tujuan keuangan. (5) Memahami anggaran menabung. (6) Memahami asuransi. (7) Menganalisis risiko, pengembalian dan likuiditas. (8) Mengevaluasi alternatifalternatif investasi. (9) Menganalisis pengaruh pajak dan inflasi terhadap hasil investasi (10) Menganalisis keuntungan dan kerugian berhutang. (10) Menjelaskan tujuan dari rekam jejak kredit dan mengenal hak-hak debitur. (11) Mendeskripsikan cara-cara untuk menghindari atau memperbaiki masalah hutang. (12) Mengetahui hukum dasar perlindungan konsumen dalam kredit dan hutang. (13) Mampu membuat pencatatan keuangan. (14) Memahami laporan neraca, laba rugi dan arus kas.

Menurut Kharchenko (2011), terdapat dua pendekatan untuk mengukur literasi keuangan :(1)Self-assessment, menurut pendekatan pertama responden diminta untuk mengevaluasi kemampuan literasi mereka dengan memberikan informasi mengenai sikap mereka terhadap keputusan keuangan, pengetahuan, dan informasi.(2)Objective measures like test score, pendekatan kedua dalam mengukur literasi keuangan bergantung pada tes objektif yang menilai pengetahuan istilah keuangan dari respoenden, memahami berbagai konsep keuangan dan kemampuan untuk mengaplikasikan kemampuan numerik dalam keadaan khusus yang berhubungan dengan keuangan. Objektif tes telah ditemukan untuk menilai pengetahuan keuangan responden dengan lebih baik dari pada self assessment.

Jenis Kelamin

Jenis kelamin (sex) adalah perbedaan antara perempuan dengan lakilaki secara biologis sejak seseorang lahir (Hungu, 2007). Menurut Ariadi, et al
(2015), jenis kelamin adalah perbedaan biologis dan fisiologis yang dapat membedakan laki-laki dan perempuan. Robb dan Sharpe (2009) mendefinisikan jenis kelamin adalah suatu konsep karakteristik yang membedakan seseorang antara laki-laki dan perempuan. Jenis kelamin adalah suatu konsep biologis dan fisiologis yang membedakan antara lakilaki dan perempuan yang tidak dapat ditukar karena keadaan alamiah manusia yang sudah melekat pada diri manusi sejak lahir (Amaliyah dan Witsiastuti, 2015).

Wanita dan pria memiliki kondisikondisi khusus yang berbeda, baik dari segi fisik biologis, maupun dari segi psikologisnya. Perbedaan tersebut merupakan sumber dari perbedaaan fungsi dan peran yang diemban oleh wanita dan pria. Jika memperhatikan perbedaan peran dan fungsi yang diemban wanita dan pria, maka akan terlihat bahwa pergerakan atau perjalanan yang dilakukan oleh wanita memiliki pola yang berbeda dengan pergerakan aau perjalanan yang dilakukan oleh pria (Amaliyah dan Witiastuti, 2015).

Menurut Krishna, et al (2010) lakilaki lebih memiliki tingkat literasi keuangan yang lebih tinggi dibandingkan wanita. Hal ini mengindikasikan bahwa laki-laki memiliki kepercayaan yang tinggi dalam membuat keputusan keuangan dibandingkan dengan perempuan lebih cenderung risk averse dibandingkan dengan laki-laki. Perempuan cenderung kurang bisa mengendalikan masalah keuangan dibandingkan dengan laki-laki. Margaretha dan Pambudhi (2015) menemukan bahwa mahasiswa perempuan memiliki tingkat literasi keuangan yang lebih tinggi dibandingkan mahasiswa lakilaki. Wijayanti, et al (2016) menemukan bahwa mahasiswa perempuan memiliki literasi keuangan yang lebih tinggi dibandingkan mahasiswa laki-laki. Perbedaan literasi keuangan antara mahasiswa laki-laki dan perempuan dikarenakan mahasiswa perempuan lebih tekun untuk mempelajari hal-hal yang berkaitan dengan konsep keuangan, serta 
lebih rajin untuk membuat perencanaan keuangannya.

Indeks Prestasi Kumulatif (IPK)

Bagi Mahasiswa, Indeks Prestasi (IP) dan Indeks Prestasi Kumulatif (IPK) menjadi salah satu hal penting yang selalu dibahas setiap akhir atau awal semester. Indeks Prestasi (IP) dan Indeks Prestasi Kumulatif (IPK) dua hal yang berbeda. Indeks Prestasi (IP) berasal dari dua kata yaitu Indeks dan Prestasi. Indeks berarti daftar menurut abjad, urutan, tanda. Sedangkan Prestasi berarti hasil yang telah dicapai. Jadi, Indeks Prestasi merupakan angka yang menunjukkan tingkat keberhasilan seorang mahasiswa dalam satu semester. Sedangkan Indeks Prestasi Kumulatif (IPK) adalah mekanisme penilaian keseluruhan prestasi terhadap mahasiswa dalam sistim perkuliahan selama kuliah.

Indeks Prestasi Kumulatif (IPK) dipengaruhi oleh nilai Indeks Prestasi (IP) dan mutu nilai setiap mata kuliah. Semakin bagus mutu nilai setiap mata kuliah, tentu nilai Indeks Prestasi Kumulatif (IPK) seorang mahasiswa akan lebih tinggi. Penilaian Indeks Prestasi Kumulatif (IPK) memiliki skala dari 0 (nol) hingga 4 (empat). Dimana angka 0 (nol) merupakan penilaian terendah dan angka 4 (empat) merupakan penilaian tertinggi dengan mutu 0 (E), 1 (D), 2 (C), 3 (B), 4 (A).

Wijayanti, et al (2016) menemukan bahwa semakin tinggi IPK mahasiswa maka literasi keuangannya juga akan meningkat. Sebaliknya semakin rendah IPK mahasiswa maka literasi keuangannya juga semakin rendah. Nababan dan Sadalia (2012) menemukan bahwa karakteristik mahasiswa dengan financial literacy tinggi adalah mahasiswa dengan IPK $\geq 3$ sedangkan mahasiswa IPK $\leq 3$ memiliki financial literacy yang rendah. Berbeda dengan Krishna, dkk (2010) menemukan mahasiswa yang memiliki IPK $<3$ tingkat literasi keuangannya lebih tinggi dibandingkan mahasiswa dengan IPK >=3. Hal ini ditentukan oleh latar belakang pendidikan. Ariani dan Susanti (2015) menemukan bahwa mahasiswa dengan IPK diatas rata-rata masuk dalam kategori financial literacy tinggi sedangkan mahasiswa IPK dibawah rata-rata masuk dalam kategori financial literacy rendah. Margaretha dan Pambudhi (2015) menunjukkan bahwa semakin tinggi IPK, maka mahasiswa akan semakin baik dalam mengelola keuangan pribadinya. Hal ini menunjukkan mahasiswa dengan indeks prestasi kumulatif (IPK) yang tinggi dimungkinkan lebih banyak memahami konsep-konsep keuangan sehingga kemampuan akademis yang tinggi akan berpengaruh secara langsung terhadap literasi keuangan mahasiswa.

Pengalaman Kerja

Menurut Kamus Bahasa Indonesia pengalaman dapat diartikan sebagai yang pernah dialami (dijalani, dirasa, ditanggung, dan sebagainya). Pengalaman kerja didefinisikan sebagai sesuatu atau kemampuan yang dimiliki oleh para karyawan dalam menjalankan tugas-tugas yang dibebankan kepadanya. Dengan pengalaman yang cukup panjang dan cukup banyak maka diharapkan mereka akan mempunyai kemampuan yang lebih besar dari pada yang tanpa pengalaman.

Orang yang berpengalaman dalam bekerja memiliki kemampuan kerja yang lebih baik dari orang yang baru saja memasuki dunia kerja, karena orang tersebut telah belajar kegiatan-kegiatan dan permasalahan yang timbul dalam kerjanya. Dengan adanya pengalaman kerja maka telah terjadi proses penambahan ilmu pengetahuan dan keterampilan serta sikap pada diri seseorang, sehingga dapat menunjang dalam mengembangkan diri dengan perubahan yang ada. Pengalaman seorang karyawan memiliki nilai yang sangat berharga bagi kepentingan karirnya di masa yang akan datang (Syafaruddin, 2008)

Pengalaman kerja menunjukkan berapa lama agar supaya karyawan bekerja dengan baik. Disamping itu pengalaman kerja meliputi banyaknya jenis pekerjaan 
atau jabatan yang pernah diduduki oleh seseorang dan lamanya mereka bekerja pada masing-masing pekerjaan atau jabatan tersebut. Dengan demikian masa kerja merupakan faktor individu yang berhubungan dengan perilaku dan persepsi individu yang mempengaruhi pengembangan karir karyawan. Pengalaman kerja menunjukkan lamanya melaksanakan, mengatasi seuatu pekerjaan dari beragam pekerjaan bahkan berulangulang dalam perjalanan hidup.

Faktor-faktor yang mempengaruhi pengalaman kerja :Karyawan yang dapat dikatakan memiliki pengalaman kerja jika sudah melakukan pekerjaan secara berulang-ulang. Adapun hal-hal yang menentukan berpengalaman atau tidaknya seorang karyawan adalah sebagai berikut : (1) Lama waktu atau masa kerja yaitu ukuran tentang lama waktu atau masa kerja yang telah ditempuh seseorang dapat memahami tugas-tugas suatu pekerjaan dan telah melaksanakan dengan baik. (2) Tingkat pengetahuan dan keterampilan yang dimiliki yaitu pengetahuan merujuk pada konsep, prinsip, prosedur, kebijakan atau informasi lain yang dibutuhkan oleh karyawan. Pengetahuan juga mencakup kemampuan untuk memahami dan menerapkan informasi pada tanggung jawab pekerjaan. Sedangkan keterampilan merujuk pada kemampuan fisik yang dibutuhkan untuk mencapai atau menjalankan suatu tugas atau pekerjaan. (3) Penguasaan terhadap pekerjaan dan peralatan yaitu tingkat penguasaan seseorang dalam pelaksanaan aspek-aspek teknik peralatan dan teknik pekerjaan. (4) Jenis pekerjaan yaitu semakin banyak jenis tugas yang dilaksanakan seseorang maka umumnya orang tersebut akan memperoleh hasil pelaksanaan tugas yang lebih baik (Sa'diyah, Endratno, 2013:78)

$$
\text { Ansong and Gyensare (2012) }
$$
menyatakan bahwa pengalaman bekerja berpengaruh terhadap literasi keuangan. Krishna, et al (2010) menemukan bahwa pengalaman bekerja secara verifikatif bepengaruh secara signifikan terhadap literasi keuangan. Shalahuddinta dan Susanti (2014) menunjukkan bahwa pengalaman bekerja memiliki pengaruh positif dan signifikan terhadap literasi keuangan mahasiswa. Dengan bekerja, mahasiswa akan memperoleh pendapatan berupa gaji atau upah. Pengelolaan keuangan saat mendapatkan gaji atau upah merupakan bentuk aplikasi yang harus diterapkan di kehidupan sehari-hari untuk mengelola pendapatan dengan tepat.

Menurut Widayati (2012) bahwa ada beberapa faktor -faktor yang mempengaruhi seorang individu dalam mengolah keuangannya dapat dilihat dari berikut : (1) Status Sosial Ekonomi Orang tua yaitu Latar belakang oroang tua, pekerjaan orang tua, jabatan social orang tua dapat mempengaruhi sikap seseorang dalam melakukan kegiatan belanja, investas, kredit, penganggaran dan pengelolaan keuangan. Menurut Ahmadi (2007 : 229) status sosial ekonomi orang tua mempunyai pengaruh terhadap tingkah laku dan pengalaman anak-anaknya. Perbedaan tingkat status sosial ekonomi akan berdampak pada munculnya perbedaan persepsi atau suatu objek fisik atau objek perilaku yang pada akhirnya membentuk sikap yang berbeda pula. (2) Pendidikan Pengelolaan Keuangan Keluarga yaitu keluarga merupakan tempat yang paling dominan dalam proses sosialisasi anak tentang masalah keuangan. Melalui pendidikan keluarga, dengan caracara yang sederhana anak di bawa ke suatu system nilai atau sikap hidup yang diingnkan dan disertai teladan orang tua yang secara tidak langsung sudah membawa anak kepada pandangan dan kebiasaan tertentu. Orang tua mengajar bagaimana anaknya bertindak dengan mengandalkan nilai-nilai, keyakinan dan pengetahuan dalam segala bidang termaksud yang berhubungan dengan keuangan. Pendidikan pengelolaan keuangan di lingkuangan keluarga dittik beratkan pada pemahaman tentang nilai uang dan penanaman sikap serta perilaku anak untuk dapat mengatur pemanfaatan 
uang. Seorang ahli kecerdasan financial anak, Cathy Malmrose menyatakan bahwa untuk memiliki keterampilan mengelola keuangan dengan baik, paling tidak seorang anak harus dilatih dalam hal menabung, melakukan pembayaran secara mandiri atas kebutuhan-kebutuhan tambahan mereka, mengelola uang saku, melakukan pekerjaan-pekerjaan rumah tertentu untuk mendapatkan uang saku tambahan, mencari pekerjaan ringan diluar rumah. (3) Pembelajaran Keuangan di Perguruan Tinggi yaitu pembelajaran hakikatnya adalah usaha dasar guru untuk membelajarkan siswanya dalam rangka mencapai tujuan yang diharapkan (Trianto, 2009:17). Pembelajaran di perguruan tinggi sangat berperan penting dalam proses pembentukan financial literacy mahasiswa. Melalui kombinasi berbagai metode pembelajaran, media dan sumber belajar yang direncanakan dengan baik dan sesuai dengan kompetensi, diharapkan mampu memberi bekal kepada mahasiswa untuk memiliki kecakapan di bidang keuangan, sehingga mahasiswa menjadi siap dan mampu menghadapi kehidupan mereka saat ini maupun masa depan yang semakin kompleks (Lutfi dan Iramani, 2008). Adapun penelitian yang terakit yaitu hasil penelitian Jhonson (2007) menyatakan bahwa pendidikan keuangan memiliki peran yang sangat penting bagi siswa untuk memiliki kemampuan memahami, menilai dan bertindak dalam kepentingan keuangan mereka.

Mahasiswa adalah seseorang yang sedang dalam proses menimba ilmu ataupun belajar dan terdaftar sedang menjalani pendidikan pada salah satu bentuk perguruan tinggi yang terdiri dari akademik, politeknik, sekolah tinggi, institut dan universitas (Hartaji, 2012:5).

Dalam Kamus Bahasa Indonesia (KBI), mahasiswa didefeniskan sebagai orang yang belajar di Perguruan Tinggi (Kamus Bahasa Indonesia Online, kbbi.web.id). Menurut Siswoyo (2007:121) mahasiswa dapat didefenisikan sebagai individu yang sedang menuntut ilmu tingkat perguruan tinggi, baik negeri maupun swasta atau lembaga lain yang setingkat dengan perguruan tinggi.

Mahasiswa dinilai memiliki tingkat intelektualisasi yang tinggi, kecerdasan dalam berfikir dengan kerencanaan dalam bertindak. Berfikir kritis dan bertindak dengan cepat dan tepat merupakan sifat yang cenderung melekat pada diri setiap mahsiswa, yang merupakan prinsip yang saling melengkapi.

Karakteristik mahasiswa secara umum yaitu stabilitas dalam kepribadian yang mulai meningkat, karena berkurangnya gejolak-gejolak yang ada didalam perasaan. Mereka cenderung memantapkan dan berpikir dengan matang terhadap sesuatu yang akan diraihnya, sehingga mereka memiliki pandangan yang realistik tentang diri sendiri dan lingkungannya. Selain itu, para mahasiswa akan cenderung lebih dekat dengan teman sebaya untuk saling bertukar pikiran dan saling memberikan dukungan, karena dapat kita ketahui bahwa sebagian besar mahasiswa berada jauh dari orang tua maupun keluarga. Karakteristik mahasiswa yang paling menonjol adalah mereka mandiri, dan memiliki perkiraan di masa depan. Mahasiswa akan memperdalam keahlian dibidangnya masing-masing untuk mempersiapkan diri menghadapi dunia kerja yang membutuhkan mental tinggi.

Kerangka pemikiran adalah suatu penjelasan sementara terhadap suatu gejala yang menjadi objek permasalahan kita, kerangka berpikir disusun dengan berdasarkan pada tinjauan pustaka dan hasil penelitian yang relevan dan terkait yang digunakan untuk membuat hipotesis. Penelitian ini terdiri dari variabel bebas, yaituJenisKelamin $\left(\mathrm{X}_{1}\right)$,

IPK $\left(\mathrm{X}_{2}\right)$,PengalamanKerja $\left(\mathrm{X}_{3}\right)$, serta variable terikatya itu Financial Literacy (Y). Adapun model penelitian dalam penelitian ini adalah sebagai berikut : 


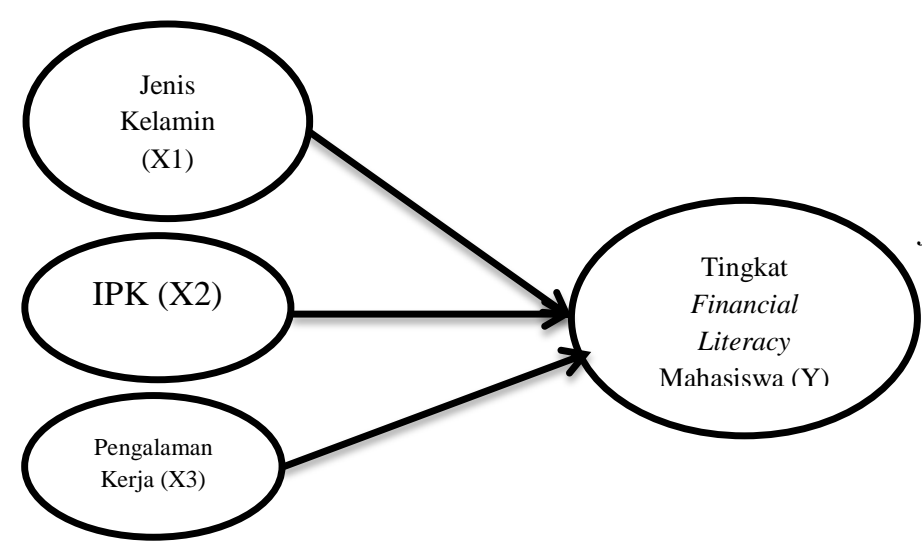

Sumber : Penelitian Terdahulu yang dikembangkan, 2017.

Gambar 1. Kerangka Permikiran

Dengan kerangka pemikiran yang ada maka dapat dirumuskan hipotesis sebagai berikut :

H1 : Jenis kelamin berpengaruh terhadap tingkat financial literacy mahasiswa Universitas Muhammadiyah Riau Pekanbaru.

H2 : Indeks prestasi kumulatif berpengaruh terhadap tingkat financial literacy mahasiswa Universitas Muhammadiyah Riau Pekanbaru.

H3 : Pengalaman kerja berpengaruh terhadap tingkat financial literacy mahasiswa Universitas Muhammadiyah Riau Pekanbaru.

\section{METODE PENELITIAN}

\section{Populasi dan Sampel}

Populasi dalam penelitian ini adalah Mahasiswa Jurusan Akuntansi Universitas Muhammadiyah Riau yang berjumlah sebanyak 1203 orang. Dalam penelitian ini, penarikan sampel menggunakan metode proportionate stratified random sampling dan menggunakan rumus slovin. Artinya dari populasi yang ada, sampel yang akan diteliti yaitu berjumlah 91 orang mahasiswa.

\section{Definisi Operasional Variabel}

Dalam penelitian ini, digunakan dua variable yaitu variable bebas (Independent variable) yang merupakan variable yang mempengaruhi variabel lain, terdiri dari Jenis Kelamin, Indeks Prestasi
Kumulatif (IPK), dan Pengalaman kerja. Ada juga variabel terikat (Dependent Variable) yang merupakan variabel yang dipengaruhi oleh variabel lain yaitu financial literacy.

Instrumen Penelitian

Untuk mengukur nilai variabel yang diteliti, maka digunakanlah instrument penelitian. Instrument penelitian yang digunakan bertujuan untuk dapat menghasilkan data kuantitatif yang akurat. Dalam penelitian ini, instrument yang peneliti gunakan berupa angket. Dalam setiap pernyataan yang tercantum dalam angket, peneliti memberikan skala pengukuran.

\section{Teknik Analisis Data Analisis Deskriptif}

Analisis deskriptif ini digunakan untuk memberikan gambaran umum mengenai jenis kelamin, indeks prestasi kumulatif, pengalaman kerja dan tingkat financial literacy Mahasiswa Jurusan Akuntanasi Fakultas Ekonomi Universitas Muhammadiyah Riau Pekanbaru. Data yang dilihat adalah jumlah data, nilai minimum, nilai maksimum, dan nilai ratarata.

\section{Uji Regresi Logistik Binier}

Analisis regresi pada dasarnya adalah studi mengenai ketergantungan variable dependen ( terikat ) dengan satu atau lebih variable independen ( variable bebas ), dengan tujuan untuk mengestimasi dan memprediksi rata-rata popukasi atau nilai rata-rata variable dependen berdasarskan nilai variable independen yang diketahui (Ghozali, 2011). Penelitian ini menggunakan analisis regresi dengan metode stepwise ( regression binary logistic ). Analisis regresi logistic biner digunakan untuk menjelaskan hubungan antara variable terikat yang berupa data dikotomik (biner) dengan variable bebasnya.

Variabel yang dikotomi atau biner adalah variable yang mempunyai dua kategori saja. Variabel dependen dan variable independen dalam penelitian ini merupakan variable dummy. Tujuan 
analisis adalah variable jenis kelamin, indeks prestasi kumulatif, dan pengalaman bekerja yang mampu menpengaruhi tingkat literasi keuangan di kalangan mahasiswa STIE Pelita Indonesia Pekanbaru 2014-2016.

Teknik analisis penelitian ini tidak memerlukan uji normalitas karena menurut Ghozali (2011) regresi logistic tidak memerlukan asumsi normalitas pada variable bebasnya. Gujarati (dalam Lestari, 2007) menyatakan bahwa regresi logistic mengabaikan heteroscedasity, artinya variable dependen tidak memerlukan homoscedacity untuk masing-masing variable independennya. Teknik ini tidak memerlukan lagi uji normalitas pada variable bebasnya (Ghozali, 2011). Tujuan dari pengujian asumsi klasik yang meliputi uji normalitas, multikolinearitas dan heteroskedastisitas adalah agar model analisis regresi yang dipakai dalam penelitian menghasilkan nilai parametric yang sah.

Pengujian hipotesis menggunakan regresi logistic tidak memerlukan uji asumsi klasik karena sebelum pengujian hipotesis dilakukan, langkah pertama yang harus dilakukan adalah menilai kelayakan mode regresi dan menilai model fit. Fungsi dari menilai kelayakan model regresi dan menilai model fir merupakan penggantian dari uji asumsi klasik. Regresi logistic tidak memiliki normalitas atas variable bebas yang digunakan dalam model. Artinya, variable penjelasnya tidak harus memilik distribusi normal linier maupun memiliki varian yang salam dalam setiap grup.

\section{HASIL DAN PEMBAHASAN Analisis Deskriptif}

Analisis deskriptif adalah suatu metode analisis dimana data-data yang ada dikumpulkan atau dikelompokkan kemudian data-data tersebut dianalisis dan diinterprestasikan secara objektif. Variabel yang digunakan dalam penelitian ini terdiri dari tiga variabel bebas, yaitu jeniskelamin $\left(\mathrm{X}_{1}\right)$, ipk $\left(\mathrm{X}_{2}\right)$ dan pengalamankerja $\left(\mathrm{X}_{3}\right)$ serta satu variabel terikat yaitu financial literacy (Y). Hasil analisis statistik deskriptif ini disarikan dalam tabel berikut

Tabel2.AnalisisDeskriptif

\begin{tabular}{|c|c|c|c|c|}
\hline \multicolumn{2}{|c|}{ Keterangan } & \multirow{2}{*}{$\begin{array}{c}\text { Frequency } \\
58\end{array}$} & \multirow{2}{*}{$\begin{array}{c}\text { Percent } \\
63.7\end{array}$} & \multirow{2}{*}{$\begin{array}{c}\begin{array}{c}\text { Valid } \\
\text { Percent }\end{array} \\
63.7\end{array}$} \\
\hline JK & Perempuan & & & \\
\hline & Laki-laki & 33 & 36.3 & 36.3 \\
\hline & Total & 91 & 100 & 100 \\
\hline IPK & $<3.00$ & 37 & 41.8 & 41.8 \\
\hline & $>3.00$ & 53 & 58.2 & 58.2 \\
\hline & Total & 91 & 100 & 100 \\
\hline \multirow[t]{3}{*}{ PK } & $\begin{array}{l}\text { Belum } \\
\text { pernah }\end{array}$ & 27 & 29.7 & 29.7 \\
\hline & $\begin{array}{l}\text { Sudah } \\
\text { pernah }\end{array}$ & 64 & 70.3 & 70.3 \\
\hline & Total & 91 & 100 & 100 \\
\hline \multirow[t]{3}{*}{ LK } & Rendah & 29 & 31.9 & 31.9 \\
\hline & Tinggi & 62 & 86.1 & 86.1 \\
\hline & Total & 91 & 100 & 100 \\
\hline
\end{tabular}

Sumber : Olahan Hasil Penelitian, 2017

Uji Logistik Biner

Pengujian hipotesis dilakukan dengan analisis multivariat yang menggunakan regresi logistik biner ( binary logistic regression ). Regresi logistik biner digunakan untuk menguji hipotesis dalama penelitian ini karena variabelnya merupakan variabel katagorikal yang mempunyai dua kategori (dummy variable) sehingga tidak dapat diselesaikan dengan menggunakan regresi berganda. Regresi logistik biner dalam penelitian ini digunakan untuk menguji pengaruh jenis kelamin, IPK, dan pengalaman kerja. Pengujian dilakukan pada tingkat signifikansi $(\alpha)$ sebesar 5\% $(0,05)$. Tingkat signifikansi menunjukan kekuatan variabel bebas dalam mempengaruhi variabel terikatnya.

\section{Pengujian Kelayakan Model Regresi}

Pengujian kelayakan model regresi pada penelitian ini menggunakan Hosmer and Lemeshow's Goodness of Fit Test. Hosmer and Lemeshow's Goodness of Fit Test menguji hipotesis nol bahwa data empiris cocok atau sesuai dengan model ( tidak ada perbedaan antara model dengan data sehingga model dapat dikatakan fit). Nilai Hosmer and Lemeshow's Goodness of Fit Test Statistics yang bernilai sama 
dengan atau kurang dari 0,05 makan hipotesis nol ditolak. Hal tersebut menunjukan bahwa terdapat perbedaan signifikan antara model yang dinilai observasinya sehingga Goodness Fit model tidak baik karena model tidak dapat memprediksikan nilai observasinya. Jika dinilai Hosmer and Lemeshow's Goodness of Fit Test Statistics lebih besar dari 0,05 maka hipotesis nol tidak dapat ditolak yang berarti model mampu memprediksikan nilai observasinya atau dapat dikatan model dapat diterima karena sesuai dengan data observasinya (Ghozali, 2011). Pengujian menggunakan Hosmer and Lemeshow's Goodness of Fit Test dapat ditampilkan dalam tabel berikut :

Tabel 3. PengujianHosmer and Lemeshow Test

\begin{tabular}{cccc}
\hline Step & Chi-Square & df & Sig. \\
\hline 1 & 1,026 & 5 & .960 \\
\hline \multicolumn{4}{l}{ Sumber $:$ Olahan Hasil Penelitian, } \\
\hline
\end{tabular}

Tabel diatas menunjukan bahwa besarnya nilai statistik pada Hosmer and Lemeshow Goodness of Fit yaitu sebesar 1,026 dengan tingkat probabilitas 0,960 yang nilainya lebih besar dari 0,05 maka Ho diterima.Hal ini menyatakan bahwa model yang dihipotesiskan fit dengan data dan layak diujikan dalam regresi logistik. Penelitian tidak menemukan perbedaan yang nyata antara klasifikasi yang diprediksi dengan klasifikasu yang diamati. Model dalam penelitian ini mampu memprediksikan nilai observasinya karena cocok dengan data observasinya.

\section{Pengujian Keseluruhan Model ( Overall Model Fit )}

Pengujian Overall Model Fit dilakukan dengan cara membandingkan nilai antara -2 Log Likelihood pada awal ( Block Number $=0$ ) dengan nilai $-2 \log$ Likelihood pada akhir (Block Number $=$ 1). Penuruan antara nilai -2 Log Likelihood awal dengan nilai -2 Log Likelihood akhir menunjukan bahwa mode yang dihipotesiskan fit dengan data (Ghozali, 2011). Perbandingan antara nilai -2 Log

Likelihood awal dengan nilai -2 Log Likelihood pada langkah berikutnya ditunjukan pada tabel berikut :

Tabel 4. Iteration History

\begin{tabular}{ccc}
\hline Iteration & $\begin{array}{c}-2 \text { Log } \\
\text { Likelihood }\end{array}$ & $\begin{array}{c}\text { Coefficients / } \\
\text { Constant }\end{array}$ \\
\hline Step 0 & 113,932 & 0,725 \\
\hline 2 & 113,909 & 0,760 \\
\hline 3 & 113,909 & 0,760 \\
\hline
\end{tabular}

Sumber : Olahan Hasil Penelitian, 2017

Tabel 5. Iteration History ${ }^{a, b, c, d}$

\begin{tabular}{cccccc}
\hline \multirow{2}{*}{ Iteration } & $\begin{array}{c}-2 \text { Log } \\
\text { likelihood }\end{array}$ & \multicolumn{4}{c}{ Coefficients } \\
\cline { 3 - 6 } & Step 1 & Constant & JK & IPK & PK \\
\hline 1 & 87,843 & 0,901 & 0,199 & 1,743 & $-0,644$ \\
\hline 2 & 85,528 & 0,427 & 0,256 & 2,117 & $-1,062$ \\
\hline 3 & 85,422 & 0,549 & 0,255 & 2,204 & $-1,202$ \\
\hline 4 & 85,422 & 0,558 & 0,255 & 2,210 & $-1,212$ \\
\hline 5 & 85,422 & 0,558 & 0,255 & 2,210 & $-1,212$ \\
\hline
\end{tabular}

Sumber : Olahan Hasil Penelitian, 2017

Hasil output nilai statistik SPSS 19

pada tabel-tabel diatas menunjukan adanya penurunan nilai -2 Log Likelihood. Nilai -2 Log Likelihood awal (tanpa variabel hanya konstanta saja) adalah 113.90. Setelah dimasukan 3 (tiga) variabel bebas maka nilai -2 Log Likelihood turun menjadi 85.42. Penurunan yang terjadi yaitu sebesar $28.48 \quad(113.90 \quad-\quad 85.42)$. Selanjutnya dengan menghitung nilai df dan membandingkan nilai penurunan -2 Log Likelihood tersebut dengan angka pada tabel c2 (sesuai df) maka akan diperoleh simpulan data tidaknya perbaikan model fit dengan penambahan tiga variabel bebas kedalam mdoel. Perhitungan nilai df adalah sebagai berikut

$\begin{aligned} \text { df } 1 \quad & =\mathrm{n}-1 \\ & =91-1 \\ & =90 \\ \text { df } 2 \quad & =\mathrm{n}-\mathrm{k} \\ & =91-4 \\ & =87 \\ \text { df } \quad & =\text { df } 1-\text { df } 2 \\ & =91-87 \\ & =3\end{aligned}$


Keterangan :

Df $=$ Degree of freedom

$\mathrm{N}$ = Jumlah sampel penelitian

$\mathrm{K}=$ Jumlah variabel dalam sampel

Berdasarkan tabel $\mathrm{c} 2$ dengan $\mathrm{df}=3$

diperoleh angka 3.18. Nilai penurunan sebesar 28.48, lebih besar dibandingkan dengan nilai c2 pada tabel $\mathrm{df}=3$ sebesar 3.18. Perbandingan tersebut menunjukan bahwa jumlah penurunan $-2 \quad \log$ Likelihood adalah signifikan. Berdasarkan uraian tersebut maka dapat disimpulkan bahwa dengan adanaya penambahan variabel independen jenis kelamin, IPK, dan pengalaman kerja dapat memperbaiki model fit.

\section{Nilai Nagelkerke R Square}

Nilai Nagelkerke $R$ Square digunakan untuk mengukur seberapa jauh kemampuan model variabel bebas secara bersamaan dalam menjelaskan variabel terikatnya. Nilai Nagelkerke $R$ Square merupakan modifikasi dari koefisien Cox \& Snell $R$ Square dan dapat diinterprestasikan seperti nilai $R$ Square pada regresi berganda (Ghozali, 2011). Nilai Nagelkerke $R$ Square ditampilkan pada tabel berikut :

Tabel 6. Model Summary

\begin{tabular}{cccc}
\hline Step & $\begin{array}{c}-2 \text { Log } \\
\text { likelihood }\end{array}$ & $\begin{array}{c}\text { Cox \& Snell } \\
\text { R Square }\end{array}$ & $\begin{array}{c}\text { Nagelkerke } \\
\text { R Square }\end{array}$ \\
\hline 1 & 85.422 & .269 & .376 \\
\hline
\end{tabular}

Sumber : Olahan Hasil Penelitian, 2017

Tabel diatas menunjukan bahwa nilai Nagelkerke $R$ Square sebesar 0376. Nilai tersebut menyatakan bahwa terdapat kontribusi dari variable jenis kelamin, IPK dan pengalaman kerja dalam memprediksi tingkat literasi keuangan secara bersamasama sebesar $37.6 \%$. Sedangkan sisanya sebesar $62.4 \%$ dipengaruhi oleh faktorfaktor lain diluar model penelitian.

\section{Hasil Uji Hipotesis}

Pengujian ini dilakukan dengan kebebasan sebesar 5\% atau 0,05 agar kemungkinan terjadinya gangguan kecil dan umum digunakan. Tabel dibawah menunjukan mengenai hasil pengujian hipotesis faktor-faktor yang mempengaruhi tingkat financial literacy di kalangan Mahasiswa Akuntansi Universitas Muhammadiyah Riau Tahun 2014-2016.

\section{Tabel 7. Omnibus Tests of Model}

Coefficients

\begin{tabular}{cccc}
\hline Step & Chi-Square & Df & Sig. \\
\hline $\begin{array}{c}\text { Step 1 } \\
\text { Step }\end{array}$ & 28.487 & 3 & .000 \\
\hline Block & 28.487 & 3 & .000 \\
\hline Model & 28.487 & 3 & .000 \\
\hline Sumber : Olahan Hasil Penelitian & 2017
\end{tabular}

Sumber : Olahan Hasil Penelitian, 2017

Uji simultan dapat dilihat pada tabel

Omnibus Test of Model Coefficients dimana jika nilai signifikansi $<0.05$ maka secara bersama-sama variable bebas berpengaruh terhadap variable terikat. Nilai Chi-square sebesar 28.487 dengan nilai signifikansi 0.000 . Hal ini menunjukan bahwa nilai signifikansi pada tabel $<0.05$. Artinya bahwa variabel Jenis Kelamin, IPK, dan Pengalaman Kerja secara simultan berpengaruh terhadap financial literacy.

Tabel 8. Variables in the Equation

\begin{tabular}{lcccccc}
\hline & B & S.E & Wald & Df & Sig. & Exp(B) \\
\hline JK & .255 & .596 & .182 & 1 & .669 & 1.290 \\
\hline IPK & 2.210 & .580 & 14.515 & 1 & .000 & 9.112 \\
\hline PK & -1.212 & .738 & 2.697 & 1 & .101 & .298 \\
\hline Constant & .558 & .718 & .605 & 1 & .437 & 1.747 \\
\hline
\end{tabular}

Sumber : Olahan Hasil Penelitian, 2017

Hasil pengujian menunjukan angka konstanta sebesar 0.558 artinya jika variabel lain (jenis kelamin, IPK, dan pengalaman kerja), maka tingkat literasi keuangan sebesar nilai konstanta. Berdasarkan tabel diatas, persamaan regresi logistic biner pada penelitian ini adalah sebagai berikut :

$$
\begin{array}{ccc}
\ln (\mathrm{p} / 1-\mathrm{p}) \quad= & 0.558+ \\
0.255+2.210-1.212+\mathrm{e} & \\
\text { Berdasarkan tabel diatas dapat }
\end{array}
$$
dilihat bahwa variabel Jenis kelamin (X1) memiliki koefisien sebesar 0.255 dengan tingkat signifikansi sebesar 0.669. Karena tingkat signifikansi lebih besar dari 0.05 ini menunjukan bahwa variabel Jenis kelamin tidak berpengaruh terhadap tingkat literasi keuangan mahasiswa.

Hasil Pengujian tabel diatas dapat dilihat bahwa variabel IPK (X2) memiliki 
koefisien sebesar 2.210 dengan tingkat signifikansi sebesar 0.000. Karena tingkat signifikansi lebih kecil dari 0.05 ini menunjukan bahwa variabel IPK berpengaruh terhadap tingkat literasi keuangan mahasiswa. Tanda positif di depan konstanta pada hasil regresi menyatakan bahwa mahasiswa dengan indeks prestasi kumulatif (IPK) $>3.00$ memiliki tingkat literasi keuangan yang lebih tinggi dibandingkan dengan mahasiswa dengan indeks prestasi kumulatif $<3.00$.

Hasil pengujian tabel diatas dapat dilihat bahwa variabel Pengalaman kerja (X3) memiliki koefisien sebesar -1.212 dengan tingkat signifikansi sebesar 0.101. Karena tingkat signifikansi lebih besar dari 0.05 ini menunjukan bahwa variabel Pengalaman kerja tidak berpengaruh terhadap tingkat literasi keuangan mahasiswa.

\section{Pengaruh Jenis kelamin terhadap Financial Literacy}

Hasil pengujian menunjukkan bahwa jenis kelamin tidak berpengaruh terhadap tingkat financial literacy di kalangan Mahasiswa Akuntansi, sehingga hipotesis pertama ditolak. Hal ini menunjukkan bahwa baik mahasiswa lakilaki maupun perempuan tidak memiliki perbedaan dalam hal memahami infomarsi keuangan. Mahasiswa fakultas ekonomi diindikasikan sudah familiar dengan istilah-istilah keuangan, bentuk-bentuk pengelolaan keuangan, produk keuangan dan sudah cukup mendapatkan pengetahuan keuangan selama kuliah. Sehingga pengetahuan umum akan keuangan, simpan pinjam, asuransi dan investasi sudah sama tingginya walaupun laki-laki lebih unggul. Baik mahasiswa laki-laki maupun perempuan Jurusan Akuntansi Universitas Muhammadiyah Riau selalu memprediksikan pengeluaran apa saja yang mereka butuhkan untuk memenuhi kebutuhan perkuliahan sehingga mereka dapat mengatur uang yang didapatkannya secara mandiri dan orang tua.
Hal ini turut didukung oleh penelitian Rita dan Pesudo (2013) dan Ariani dan Susanti (2015) bahwa variabel jenis kelamin tidak memiliki pengaruh yang signifikan terhadap literasi keuangan mahasiswa, hal itu ditunjukkan dengan kategori literasi keuangan mahasiswa atau mahasiswi yang sama tinggi.

Hasil analisis statistik deskriptif menunjukkan bahwa jumlah mahasiswa perempuan lebih dominan dari pada mahasiswa laki-laki. Secara deskriptif mahasiswa perempuan berpengaruh terhadap financial literacy.Dan hasil statistik menunjukkan bahwa laki-laki mempunyai pengaruh secara parsial meskipun jumlah mahasiswa laki-laki lebih kecil. Penemuan ini didukung oleh penelitian yang dilakukan Nababan dan Sadalia (2012) menyatakan bahwa karakteristik financial literacy yang tinggi adalah mahasiswa laki-laki, mahasiswi perempuan memiliki rata-rata tingkat personal financial literacy berada dibawah rata-rata secara keseluruhan.

\section{Pengaruh IPK terhadap Financial Literacy}

Hasil pengujian menunjukkan bahwa indeks prestasi kumulatif (IPK) berpengaruh terhadap tingkat financial literacy di kalangan Mahasiswa Akuntansi, sehingga hipotesis kedua diterima. Berpengaruh disini bermakna bahwa mahasiswa dengan IPK >3.00 maka financial literacynya juga tinggi. Sebaliknya, mahasiswa dengan IPK $<3.00$ maka financial literacynya rendah.

Perbedaan literasi keuangan antara mahasiswa yang memiliki IPK yang tinggi (>3.00) dan IPK yang rendah $(<3.00)$ dikarenakan mahasiswa yang memiliki IPK lebih tinggi pada umumnya mampu memahami setiap materi perkuliahan lebih baik dari pada mahasiswa yang memiliki IPK lebih rendah $(<3.00)$. Sehingga menyebabkan pengetahuan keuangan mahasiswa berbeda antara satu dengan yang lain.

Perbedaan kemampuan memahami konsep keuangan pada saat perkuliahan 
membuat mahasiswa yang ber-IPK tinggi (>3.00) cenderung memiliki konsep keuangan yang lebih baik dari pada mahasiswa yang ber-IPK lebih rendah $(<3.00)$ seperti menabung secara periodik, memiliki catatan pengeluaran setiap bulannya dan menyediakan dana untuk pengeluaran tak terduga.

Hasil analisis statistik deskriptif mendukung hasil analisis statistk secara parsial dimana mahasiswa yang memiliki indeks prestasi kumulatif $>3.00$ memiliki tingkat pengetahuan keuangan yang lebih tinggi. Hal ini terlihat dari keseluruhan responden memiliki indeks prestasi kumulatif yang tinggi.

Hasil penelitian ini sesuai denganhasil penelitian yang dilakukan Wijayanti et al (2016), Ariani dan Susanti (2015) menyatakan bahwa mahasiswa yang memiliki indeks prestasi kumulatif(IPK) yang tinggi memiliki tingkat literasi keuangan yang lebih tinggi dibandingkan dengan mahasiswa yang memiliki indeks prestasi kumulatif (IPK) yang rendah. Nababan dan Sadalia (2012) mengakui bahwa tingkat intelektualitas mahasiswa dapat memberikan dampak positif terhadap financial literacy. Hal ini juga berlaku pada mahasiswa jurusan Akuntansi Universitas Muhammadiyah Riau dimana tingkat intelektual mahasiswa dapat menggambarkan tingkat literasi keuangan yang tinggi. Pada akhirnya, tingkat literasi keuangan mahasiswa dengan IPK >3.00 lebih baik dari pada mahasiswa dengan IPK <3.00. Dan hasil penelitian ini juga mendukung hasil penelitian yang dilakukan oleh Margaretha dan Pambudhi (2015) yang mengungkapkan bahwa semakin tinggi IPK, maka mahasiswa akan semakin baik dalam mengelola keuangan pribadinya (literasi keuangan).

\section{Pengaruh Pengalaman Kerja terhadap Financial Literacy}

Hasil pengujian menunjukkan bahwa pengalaman kerja tidak berpengaruh terhadap tingkat financial literacy di kalangan Mahasiswa Akuntansi, sehingga hipotesis ketiga ditolak. Hal ini disebabkan mahasiswa yang belum pernah memiliki pengalaman kerja ataupun sudah pernah memiliki pengalaman kerja tidak banyak mendapatkan pengetahuan keuangan dari lingkungan kerjanya.

Mahasiswa yang bekerja secara rutin atau part time membuat mahasiswa tidak berinteraksi dengan maksimal di lingkungan tersebut karena harus membagi waktu untuk kuliah, mengerjakan tugas dan kumpul dengan teman maupun keluarga. Walaupun mahasiswa bekerja namun keinginan untuk fokus dan maksimal dalam perkuliahan juga sangat tinggi. Hal lain yang dapat mempengaruhi rendahnya pengetahuan keuangan mahasiswa seperti keterbatasan waktu karena sudah sibuk bekerja sehingga tidak fokus dalam perkuliahan dan jarangnya mengikuti seminar ekonomi yang diasakan kampus ataupun diluar kampus.

Hasil analisis deksriptif menunjukkan bahwa mahasiswa yang sudah pernah bekerja memiliki pengaruh terhadap tingkat financial literacy karena diindikasikan sudah familiar dengan produk keuangan. Tetapi berdasarkan hasil analisis statistik tidak berpengaruh yang disebabkan besarnya faktor-faktor lain yang berpengaruh terhadap financial literacy seperti pembelajaran di perguruan tinggi atau status sosial ekonomi orang tua.

Hasil penelitian ini didukung dengan hasil penelitian Ariani dan Susanti (2015) menunjukkan bahwa pengalaman bekerja tidak berpengaruh secara signifikan terhadap financial literacy mahasiswa FE UNESA. Mahasiswa yang memiliki pengalaman bekerja $>1$ tahun atau yang memiliki pengalaman bekerja 0-1 tahun sama-sama memiliki financial literacy relatif tinggi.

\section{PENUTUP \\ Kesimpulan}

Adapun kesimpulan yang dapat ditarik dari hasil penelitian yang telah dilakukan menunjukan bahwa berdasarkan ujian analisis logistic binier yaitu factor 
Jenis kelamin tidak berpengaruh terhadap financial literacy Mahasiswa Jurusan Akuntansi Universitas Muhammadiyah Riau Pekanbaru. Pada faktor Indeks Prestasi Kumulatif (IPK) hasil penelitian menunjukkan bahwa IPK berpengaruh terhadap financial literacy Mahasiswa Jurusan Akuntansi Universitas Muhammadiyah Riau Pekanbaru, artinya mahasiswa dengan IPK >3.00 maka financial literacynya lebih tinggi dibandingkan dengan mahasiswa IPK <3.00. Dan berdasarkan hasil penelitian menunjukkan bahwa faktor Pengalaman Kerja tidak berpengaruh terhadap financial literacy Mahasiswa Jurusan Akuntansi Universitas Muhammadiyah Riau Pekanbaru.

\section{Saran}

Berdasarkan hasil penelitian dan analisis data yang telah dilakukan, maka saran-saran yang dapat diberikan adalah Bagi Mahasiswa disarankan lebih proaktif untuk belajar aspek-aspek keuangan terutama aspek investasi dan tabungan karena investasi dan tabungan merupakan jenis pengalokasian dana yang paling memberikan manfaat di masa depan. Mahasiswa juga disarankan untuk selalu peka terhadap segala informasi berkaitan dengan keuangan agar memiliki financial literacy yang cukup tinggi sehingga dapat terhindat dari masalah keuangan.

Peneliti Selanjutnya disarankan untuk menambah variabel lannya seperti tempat tinggal, pendidikan orang tua, pendapatan rang tua dan pendidikan pengelolaan keuangan keluarga serta melakukan analisis lebih lanjut mengenai pengaruh setiap variabel bebas terhadap elemen financial literacy.

Universitas Muhammadiyah Riau dan para pendidik perlu memberikan informasi tambahan bagi mahasiswa mengenai pengetahuan umum keuangan pribadi dengan cara lebih sering mengadakan seminar atau kuliah umum mengenai konsep keuangan pribadi guna meningkatkan financial literacy dan kemampuan mengelola keuangan pribadi mahasiswa.

\section{DAFTAR PUSTAKA}

Ahmadi, A. (2007). Psikologi Sosial. Jakarta : Rineka Cipta.

Amaliyah, Riski dan Rini Setyo Witiastuti. (2015). Analisis Faktor yang Mempengaruhi Tingkat Literasi Keuangan di Kalangan UMKM Kota Tegal. Management Analysis Journal, 4(3):252-257.

Arif, Kashif. (2015). Financial Literacy and other Factors Influecing Individuals' Investment Desicion : Evidence from a Developing Economy (Pakistan). Journal of Poverty, Investment and Development: An International Peereviewed Journal, 12:74-84.

Ariadi, (2015). Analisa Hubungan Financial Literacy dan Demografi dengan Investasi, Saving dan Konsumsi. Journal of Finsta, 3(1): 7-12.

Ariani, Nur Aziza dan Susanti. (2015). Pengaruh Faktor Demografi terhadap Financial Literacy Mahasiswa Fakultas Ekonomi Universitas Negeri Angkatan 2012. Fakultas Ekonomi, Universitas Negeri Surabaya.

Ansong, A. And Gyensare, MA. (2012). Determinants of University Working-Students' Financial Literacy at the University of Cape Coast, Ghana. International Journal of Business Management, 7(9):126-133.

Bhushan, P., \& Medury, Y. (2013). Financial Literacy an Its Determinants. International Journal of Engineering, Business and Interprise Apllications (IJABEA), 4 (2), 155-160.

Ghozali, Imam. (2009). Aplikasi Analisi Multivariate dengan Program SPSS. Semarang:Undip. 
Hartaji, Damar A. (2012). Motivasi Berprestasi pada Mahasiswa yang Berkuliah dengan Jurusan Pilihan Orang Tua. Fakultas Psikologi Universitas Gunadarma.

Hungu. (2007). Demografi Kesehatan Indonesia. Jakarta: Penerbit Grasindo.

Huston, Sandra J. (2010). Measuring Financial Literacy. The Journal of Consumer Affiars, 44(2): 296-315.

Jhonson, E \& Margaret S.S. (2007). From Financial Literacy to Financial Capability Among The Young. Journal of Sociology and Social Welfane, 34. 119-146.

Kardinal. (2015). Kontribusi Literasi Keuangan terhadap Penggunaan Produk Keuangan pada Masyrakat Indonesia. Proceeding Sriwijaya Economic and Business Conference 2015. 574-589. Palembang : Universitas Negeri Sriwijaya.

Kharchenko, Olga. (2011). Financial Literacy in Ukraine : Determinants and Implication for Saving Behaviour. Ukraine : Kyiv School of Economic.

Krishna, (2010). Analisis Tingkat Literasi Keuangan di Kalangan Mahasiswa dan Faktor-faktor yang Mempengaruhinya. Proceedings of the $4^{\text {th }}$ International Conference on Teacher Education ; Join Conference UPI \& UPSI Bandung, Indonesia. 552-560.

Lestari, Dewi Puji. (2007). Pengaruh Rasuo Likuiditas dan Profitabilitas terhadap Penerimaan Opini Audit Going Concern pada Perusahaan Manufaktur.

Lusardi, A. and O. S. Mitchell. (2006). Financial Literacy and Planning Implications for Retirement Wellbeing. Pension Research Council Working Paper 1, The Wharton School.
Lusardi, A, O. S. Michell, and Curto, V. (2010). Financial Literacy among the Young : Evidence and Implications for Consumer Policy. NBER Working Paper, 15352.

Lutfi \& Iramani. (2008). Financial Literacy Among University Student and Its Implication to the Teaching Method. Surabaya. STIE Perbanas Surabaya.

Manurung, Jonni J., dan Adler $\mathrm{H}$. Manurung. (2009). Ekonomi Keuangan dan Kebijakan Moneter. Cetakan Pertama. Jakarta : Salemba Empat.

Margaretha, Farah dan Reza Arief Pambudhi. (2015). Tingkat Literasi Keuangan pada Mahasiswa S-1 Fakultas Ekonomi. JMK. Volume 17 No. 1. Maret 2015. 76-85.

Mendari, Anastasia Sri dan Suramaya Suci Kewal. (2014). Tingkat Literasi di Kalangan Mahasiswa STIE MUSI. 130-140.

Nababan, Darman dan Isfenti Sadalia. (2012). Analisis Personal Financial Literacy dan Financial Behaviour Mahasiswa Strata I Fakultas Ekonomi Universitas Sumatera Utara. Medan:Fakultas Ekonomi dan Bisnis Universitas Sumatera Utara.

Orton, Larry. (2007). Financial Literacy: Lessons from International Experience. CPRN Research Report September 2007. Ontario: Canadian Policy Research Networks Inc.

Otoritas Jasa Keuangan. (2014). Strategi Nasional Literasi Keuangan Indonesia. Jakarta.

Rasyid, Rosyeni. (2012). Analisis Tingkat Literasi Keuangan Mahasiswa Program Studi Manajemen Fakultas Ekonomi Universitas Negeri Padang. Jurnal Kajian Manajemen Bisnis, 1(2):91-106. 
Remund, D. (2010). Financial Literacy Expliced, Tthe Case For a Clearer Defenition in a Increasingly Complex Economy. Journal of Consumer Affair Summer, 44 (2) : 176-295.

Rita, Maria Rio dan B.C.A.Pesudo. (2014). Apakah Mahasiswa Sudah Melek Keuangan?. Journal Dinamika Akuntansi, Keuangan dan Perbankan, Mei 2014, 3(1).5865.

Robb, C. and Deanna L. Sharpe. (2009). Effect of Personal Financial Knowledge onCollege Student's Credit Card Behavior. Journal of Financial Counseling and Planning, 20:1.

Shalahuddinta, Alfin dan Susanti. (2014). Pengaruh Pendidikan Keuangan di Keluargam Pengalaman Bekerja dan Pembelajaran di Perguruan Tinggi terhadap Literasi Keuangan. Universitas Negeri Surabaya.

Siswoyo, Dwi. (2007). Ilmu Pendidikan ; Jogjakarta.

Syafaruddin, Alwi. (2008). Manajemen Sumber Daya Manusia Strategi Keungggulan Kompetitif. BPFEYogyakarta. Yogyakarta.

Trianto. (2009). Mendesain Model Pembelajaran Inovatif Progresif. Jakarta : Kencana Prenada Media Group.

Widayati, Irin. (2012). Faktor-faktor yang Mempengaruhi Literasi Finansial Mahasiswa Fakultas Ekonomi dan Bisnis Universitas Brawijaya. Journal Akuntansi dan Pendidikan, Volume 1 No. 1.Hal.89-99.

Wijayanti, (2016). Pengaruh Jenis Kelamin, IPK, dan Semester terhadap Literasi Keuangan Mahasiswa Prodi S1 Ekonomi Pembangunan Universitas Negeri Malang. JPE, 9(1):102-115. 